\section{俩 Heighten Science P U B L I C I T I O N S Corporation ISSN 2576-9537}

\title{
Clinical Significance of Urinary Amylase in Acute Pancreatitis
}

\author{
Mumtaz Din Wani ${ }^{1}$, Mushtaq Chalkoo ${ }^{2 *}$, Zaheer Ahmed ${ }^{3}$, \\ Awhad Mueed Yousuf ${ }^{3}$, Yassar Arafat ${ }^{3}$, Syed Shakeeb Arsalan ${ }^{3}$ \\ and Jaffar Hussain ${ }^{3}$ \\ 'Professor of Surgery, Government Medical College Srinagar, India \\ ${ }^{2}$ Assistant Professor, Government Medical College, Srinagar, India \\ ${ }^{3}$ Postgraduate Department of Surgery, Government Medical College Srinagar, India
}

\begin{abstract}
*Address for Correspondence: Dr. Mushtaq Chalkoo, Assistant Professor, Govt. Medical College, Srinagar, Kashmir, India, Email: Mushtaq_chalkoo@rediffmail.com

Submitted: 03 June 2017

Approved: 23 June 2017

Published: 27 June 2017

Copyright: $\circledast 2017$ Wani MD, et al. This is an open access article distributed under the Creative Commons Attribution License, which permits unrestricted use, distribution, and reproduction in any medium, provided the original work is properly cited.
\end{abstract}

Keywords: Acute Pancreatitis; Biochemical markers

\section{ABSTRACT}

Acute pancreatitis forms a major bulk of our inpatient admission due to gall stone disease. Diagnosis of acute pancreatitis remains a challenge even now. Serum amylase remains the most commonly used biochemical marker for its diagnosis but its sensitivity can be reduced by late presentation, hyper-triglyceridemia and chronic alcoholism. We conducted a study to determine the levels of serum and urinary amylase in patients with acute pancreatitis and compared their sensitivity and correlation with CT findings vis-à-vis the severity of the disease. The study was taken as a post graduate research model in the Post graduate Department of General and Minimal Access Surgery, Govt. Medical College Srinagar, J\&K, India 2014-2016 and submitted for the award of masters in General Surgery. A total number of 150 patients were enrolled in the studies which were admitted in our unit as acute pancreatitis. $73(48.7 \%$ ) belonged to the age group of $30-44$ years, $15(10 \%)$ patients aged $>60$ years with $86(57.3 \%)$ males and $64(42.7 \%)$ females. We had $81(54 \%)$ patients with biliary tract diseases, followed by $21(14 \%)$ patients with worm induced, $20(13.3 \%)$ had hyperlipidaemia and only $4(2.7 \%)$ patients had post ERCP etiology. Tenderness in epigastrium was the presenting sign in $111(74 \%)$, followed by chest signs in 25 (16.7\%) patients, diffuse tenderness in $19(12.7 \%)$, icterus in $11(7.3 \%)$, low grade fever in $9(6 \%)$ patients, shock in $5(3.3 \%)$. Diabetes mellitus as a comorbidity was observed in $48(32 \%)$ patients followed by hypothyroidism $37(24.7 \%)$ patients. Hypertension was seen in $31(20.7 \%)$ patients, COPD in $19(12.7 \%)$ patients and obesity in $13(8.7 \%)$ patients. Twenty two $(14.7 \%)$ needed ICU admission; while as $128(85.3 \%)$ were managed in the general ward. All the enrolled patients in our study were managed conservatively. Out of a total of 150 patients, $148(98.7 \%)$ survived while as only $2(1.3 \%)$ of our patients expired. At the time of admission in the hospital, 120 (80\%) patients had serum amylase level of $>450 \mathrm{U} / \mathrm{L}, 19(12.7 \%)$ patients had 150-450 U/L levels while as 11 (7.3\%) patients had $<150 \mathrm{U} / \mathrm{L}$ serum amylase levels. CT has been shown to yield an early overall detection rate of $90 \%$ with close to $100 \%$ sensitivity after 4 days for pancreatic gland necrosis. The correlation of urinary amylase with the CECT Severity Scoring in a patient of acute pancreatitis is still ambiguous.

\section{INTRODUCTION}

Acute pancreatitis (AP) is a disease with wide clinical variation, which makes its diagnosis complex. Serum / urinary amylase measurement is a standard diagnostic method, although it was shown to be unable to recognize one fifth of acute pancreatitis patients [1]. The severity of acute pancreatitis forms a continuum, and the average mortality rate approaches $2-10 \%$ [2-4]. Most of the cases are mild and conservative treatment results in a rapid recovery in most of them. However, severe acute pancreatitis constitutes $15-20 \%$ of all cases [5,6]. Beger and co-workers [7], showed an overall contamination rate of pancreatic necrosis of $24 \%$ within the first week after the onset of acute pancreatitis in patients undergoing surgery for severe acute pancreatitis, increasing to $46 \%$ in the second and to $71 \%$ in the third week.

The major function of pancreatic acinar cells is the synthesis and secretion of inactive digestive enzyme precursors (trypsinogen, chymotrypsinogen, proelastase, procarboxypeptidases A and B and prophospholipase A2) into the duodenum [8,9]. 
Zymogens are synthesized in the endoplasmic reticulum and then packaged into secretory granules. Following acinar cell stimulation, the contents of these granules are discharged by exocytosis into the acinar lumen and pass via the pancreatic ductal system into the duodenum, where the conversion of trypsinogen to trypsin is catalysed by enterokinase $[10,11]$. Trypsin is the key enzyme for rapid activation of all the proenzymes, including its own proenzyme, trypsinogen [12]. There are two major isoenzymes of trypsinogen: trypsinogen-1 and trypsinogen-2.

In healthy subjects, the ratio of trypsinogen-1 to trypsinogen-2 in pancreatic fluid is nearly fourfold [13]. Trypsinogen is activated by proteolytic cleavage of a peptide called trypsinogen activation peptide (TAP) $[14,15]$. Owing to their potent proteolytic and lipolytic functions, the secretory enzymes represent a considerable degradative (autodigestive) capacity. Compartmental intracellular transport, synthesis of secretory enzymes as inactive zymogens, and the presence of protease inhibitors intracellularly (pancreatic secretory trypsin inhibitor) and in blood (e.g. alpha-1-antitrypsin and alpha-2-macroglobulin) are major protective mechanisms [16,17].

The pathogenesis of acute pancreatitis is only partially known. The initial phase involves triggering events, which are, for the most part, extrapancreatic in origin. Clinically, the most important of these appears to be either passage of a biliary tract stone or ingestion of ethanol. Although the clinical association of acute pancreatitis with biliary disease and with ethanol ingestion has been firmly established, mechanistic explanations for these associations have proven elusive [18]. In experimental acute pancreatitis, microscopic examination of pancreatic tissue obtained after common bile-pancreatic duct ligation indicates that the earliest signs of cell injury involve acinar cells [19]. The severity of experimental acute pancreatitis has been directly related to the duration of duct obstruction [20].

The diagnosis of acute pancreatitis is problematic while there are no specific clinical signs. Patients with acute pancreatitis may suffer from a multitude of symptoms, including upper abdominal pain, meteorism, abdominal resistance, fever, nausea and vomiting, ileus and jaundice. None of these frequent symptoms are related to the severity of the disease. Rare clinical findings, such as ecchymosis of the flank (Grey Turner sign) or periumbilical area (Cullen sign), which occur in 1-3\% of patients; also fail to effectively predict the severity of acute pancreatitis [21]. Within the first days of admission patients with severe acute pancreatitis may develop SIRS characterized by a combination of fever, tachycardia, and tachypnoea [22].

\section{SEVERITY ASSESSMENT OF ACUTE PANCREATITIS}

Early identification of potentially severe acute pancreatitis is of utmost importance. Acute Pancreatitis patients with delayed transfer to intensive care have higher mortality to those admitted directly, and mortality even increases when transfer is delayed [23]. There is evidence for benefits of early intensive monitoring and support, enteral feeding, prophylactic antibiotics and emergency endoscopic sphincterotomy in patients with biliary etiology in severe acute pancreatitis [24,25]. Magnetic resonance imaging is increasingly used for assessing the severity of acute pancreatitis with quite promising results [26].

\section{AIMS AND OBJECTIVES}

- To study the pattern of urine amylase in patients admitted as acute pancreatitis.

- To correlate urine amylase levels with CT findings.

\section{MATERIALS AND METHODS}

After obtaining the ethical clearance from the institutional ethical committee, the present study was conducted in the Postgraduate Department of General Surgery, Government Medical College Srinagar. All patients admitted with pancreatitis were included in the study over a period of two year 2014-2016. The criteria for a diagnosis of acute pancreatitis; characteristic clinical findings (typical epigastric pain, nausea, and vomiting) and very high amylase concentrations more than 3 times normal. Clinical 
findings combined with an elevated amylase concentration and CT or ultrasonographic findings typical of acute pancreatitis; or a characteristic clinical presentation and positive findings on contrast-enhanced CT in patients without an elevated amylase.

Patients admitted with pancreatitis were evaluated clinically and were investigated as per the preformed proforma specifically serum amylase was send. After admission 2 hour urine amylase was sent followed by 24 hour urine amylase investigation and at the time of discharge.

CT scan was done after 48 to 72 hours of admission. On the basis of CT findings patients were divided into three categories viz: Mild Acute Pancreatitis (CTSI 0-3), Moderate Pancreatitis (CTSI 4-6) and Severe Acute Pancreatitis (CTSI 7-10). Urine amylase levels were then correlated with the CT findings. Method of urine amylase $\rightarrow$ Enzyme Calorimetric Assay.

\section{STASTISTICAL ANALYSIS}

Statistical Software SPSS (Version 20.0) and Microsoft excel were used to carry out the statistical analysis of data. Descriptive Statistics of data including the mean and standard deviation for numerical variables and the percentages of different categories for categorical variables was obtained. Frequency distribution tables (Tables 1-16 and Charts 1-14), bar and pie charts were used for data presentation. Chi-square test was employed to determine the association of urinary amylase with severity of acute pancreatitis. P-value less 0.05 was considered statistically significant. All p-values were two tailed.

Table 1: Age distribution of Studied Patients.

\begin{tabular}{|c|c|c|}
\hline Age & No. of Patients & Percentage \\
\hline $15-29$ & 28 & 18.7 \\
\hline $30-44$ & 73 & 48.7 \\
\hline $45-59$ & 34 & 22.7 \\
\hline$\geq 60$ & 15 & 10.0 \\
\hline Total & $\mathbf{1 5 0}$ & $\mathbf{1 0 0}$ \\
\hline Mean \pm SD $=40.5 \pm 12.3$ & & \\
\hline
\end{tabular}

Table 2: Gender distribution of patients.

\begin{tabular}{|c|c|c|}
\hline Gender & No. of Patients & Percentage \\
\hline Male & 86 & 57.3 \\
\hline Female & 64 & 42.7 \\
\hline Total & $\mathbf{1 5 0}$ & $\mathbf{1 0 0}$ \\
\hline
\end{tabular}

Table 3: Distribution of studied patients on the basis of etiology.

\begin{tabular}{|c|c|c|}
\hline Etiology & No. of Patients & Percentage \\
\hline Biliary Tract Disease & 81 & 54.0 \\
\hline Alcohol & 9 & 6.0 \\
\hline Hyperlipidemia & 20 & 13.3 \\
\hline Post ERCP & 4 & 2.7 \\
\hline Drug Induced & 5 & 3.3 \\
\hline Worm Induced & 21 & 14.0 \\
\hline Others & 10 & 6.7 \\
\hline Total & $\mathbf{1 5 0}$ & $\mathbf{1 0 0}$ \\
\hline
\end{tabular}

Table 4: Showing symptoms at presentation in studied patients.

\begin{tabular}{|c|c|c|}
\hline Symptoms at Presentation & No. of Patients & Percentage \\
\hline Pain Epigastrium & 113 & 75.3 \\
\hline Vomiting & 87 & 58.0 \\
\hline Pain Whole Abdomen & 29 & 19.3 \\
\hline Jaundice & 11 & 7.3 \\
\hline Abdomen Distension & 5 & 3.3 \\
\hline
\end{tabular}


Table 5: Distribution of studied patients on the basis of presenting signs.

\begin{tabular}{|c|c|c|}
\hline Signs & No. of Patients & Percentage \\
\hline Tenderness in Epigastrium & 111 & 74.0 \\
\hline Diffuse Tenderness & 19 & 12.7 \\
\hline Flank and Periumblical Ecchymosis & 0 & 0.0 \\
\hline Icterus & 11 & 7.3 \\
\hline Low Grade Fever & 9 & 6.0 \\
\hline Shock & 5 & 3.3 \\
\hline Chest Signs & 25 & 16.7 \\
\hline
\end{tabular}

Table 6: Showing associated comorbidites in studied patients.

\begin{tabular}{|c|c|c|}
\hline Comorbidities & No. of Patients & Percentage \\
\hline Diabetes Mellitus & 48 & 32.0 \\
\hline Hypertension & 31 & 20.7 \\
\hline Hypothyroidism & 37 & 24.7 \\
\hline Obesity & 13 & 8.7 \\
\hline COPD & 19 & 12.7 \\
\hline
\end{tabular}

Table 7: Showing requirement of ICU management among studied patients.

\begin{tabular}{|c|c|c|}
\hline ICU Requirement & No. of Patients & Percentage \\
\hline Yes & 22 & 14.7 \\
\hline No & 128 & 85.3 \\
\hline Total & $\mathbf{1 5 0}$ & $\mathbf{1 0 0}$ \\
\hline
\end{tabular}

Table 8: Distribution of studied patients on the basis of management.

\begin{tabular}{|c|c|c|}
\hline Management & No. of Patients & Percentage \\
\hline Conservative & 150 & 100 \\
\hline Surgery & 0 & 0 \\
\hline Total & $\mathbf{1 5 0}$ & $\mathbf{1 0 0}$ \\
\hline
\end{tabular}

Table 9: Showing outcome in studied patients.

\begin{tabular}{|c|c|c|}
\hline Outcome & No. of Patients & Percentage \\
\hline Survived & 148 & 98.7 \\
\hline Deaths & 2 & 1.3 \\
\hline Total & $\mathbf{1 5 0}$ & $\mathbf{1 0 0}$ \\
\hline
\end{tabular}

Table 10: Showing pattern of serum amylase at admission in studied patients.

\begin{tabular}{|c|c|c|}
\hline Serum Amylase & No. of Patients & Percentage \\
\hline$<150 \mathrm{U} / \mathrm{L}$ & 11 & 7.3 \\
\hline $150-450 \mathrm{U} / \mathrm{L}$ & 19 & 12.7 \\
\hline$>450 \mathrm{U} / \mathrm{L}$ & 120 & 80.0 \\
\hline Total & $\mathbf{1 5 0}$ & $\mathbf{1 0 0}$ \\
\hline
\end{tabular}

Table 11: Showing pattern of urine amylase at admission in studied patients.

\begin{tabular}{|c|c|c|}
\hline Urine Amylase At Admission & No. of Patients & Percentage \\
\hline$<400 \mathrm{U} / \mathrm{L}$ & 3 & 2.0 \\
\hline $400-1000 \mathrm{U} / \mathrm{L}$ & 34 & 22.7 \\
\hline $1000-2000(\mathrm{U} / \mathrm{L})$ & 65 & 43.3 \\
\hline$\geq 2000 \mathrm{U} / \mathrm{L}$ & 48 & 32.0 \\
\hline Total & $\mathbf{1 5 0}$ & $\mathbf{1 0 0}$ \\
\hline
\end{tabular}

Table 12: Showing association of urinary amylase with serum amylase at admission.

\begin{tabular}{|c|c|c|c|c|c|c|}
\hline \multirow{2}{*}{ Urinary amylase } & \multicolumn{2}{|c|}{$<\mathbf{1 5 0} \mathrm{U} / \mathrm{L}$} & \multicolumn{2}{c|}{$\mathbf{1 5 0 - 4 5 0}$ U/L } & \multicolumn{2}{c|}{$>\mathbf{4 5 0}$ U/L } \\
\hline & No. & \%age & No. & \%age & No. & $\%$ age \\
\hline$<400 \mathrm{U} / \mathrm{L}$ & 2 & 18.2 & 0 & 0.0 & 1 & 0.8 \\
\hline $400-1000 \mathrm{U} / \mathrm{L}$ & 2 & 18.2 & 9 & 47.4 & 23 & 19.2 \\
\hline $1000-2000$ (U/L) & 7 & 63.6 & 7 & 36.8 & 51 & 42.5 \\
\hline$\geq 2000 \mathrm{U} / \mathrm{L}$ & 0 & 0.0 & 3 & 15.8 & 45 & 37.5 \\
\hline Total & $\mathbf{1 1}$ & $\mathbf{1 0 0}$ & $\mathbf{1 9}$ & $\mathbf{1 0 0}$ & $\mathbf{1 2 0}$ & $\mathbf{1 0 0}$ \\
\hline Chi-square=28.9; P-value<0.001 & & & & & & \\
\hline
\end{tabular}


Table 13: Showing pattern of urine amylase at 24 hours of admission in studied patients.

\begin{tabular}{|c|c|c|}
\hline Urine Amylase at 24 Hours & No. of Patients & Percentage \\
\hline$<400 \mathrm{U} / \mathrm{L}$ & 2 & 1.3 \\
\hline $400-1000 \mathrm{U} / \mathrm{L}$ & 32 & 21.3 \\
\hline $1000-2000(\mathrm{U} / \mathrm{L})$ & 67 & 44.7 \\
\hline$\geq 2000 \mathrm{U} / \mathrm{L}$ & 49 & 32.7 \\
\hline Total & $\mathbf{1 5 0}$ & $\mathbf{1 0 0}$ \\
\hline
\end{tabular}

Table 14: Showing pattern of urine amylase at discharge in studied patients.

\begin{tabular}{|c|c|c|}
\hline Urine Amylase At Discharge & No. of Patients & Percentage \\
\hline$<400 \mathrm{U} / \mathrm{L}$ & 4 & 2.7 \\
\hline $400-1000 \mathrm{U} / \mathrm{L}$ & 26 & 17.3 \\
\hline $1000-2000(\mathrm{U} / \mathrm{L})$ & 69 & 46.0 \\
\hline$\geq 2000 \mathrm{U} / \mathrm{L}$ & 51 & 34.0 \\
\hline Total & $\mathbf{1 5 0}$ & $\mathbf{1 0 0}$ \\
\hline
\end{tabular}

Table 15: Computed tomography severity index (CTSI) for acute pancreatitis.

\begin{tabular}{|c|c|c|}
\hline & Feature & Points \\
\hline \multirow{4}{*}{$\begin{array}{c}\text { Pancreatic } \\
\text { Inflammation }\end{array}$} & Focal or Diffuse Pancreatic Enlargement & 0 \\
\cline { 2 - 3 } & $\begin{array}{c}\text { Intrinsic Pancreatic Alterations with Peri-Pancreatic Fat } \\
\text { Inflammatory Changes }\end{array}$ & 1 \\
\cline { 2 - 3 } & Two or more fluid collections or gas in or adjacent to \\
& pancreas & 2 \\
\hline \multirow{3}{*}{$\begin{array}{c}\text { Pancreatic } \\
\text { Necrosis }\end{array}$} & None & 3 \\
\hline & $\leq 30 \%$ & 4 \\
\hline & $30 \%-50 \%$ & 0 \\
\hline
\end{tabular}

Table 16: Showing CECT Findings in Studied Patients.

\begin{tabular}{|c|c|c|c|}
\hline CECT Findings & CTSI Score & No. of Patients & Percentage \\
\hline Mild Acute Pancreatitis & $0-3$ & 85 & 56.7 \\
\hline Moderate Acute Pancreatitis & $4-6$ & 52 & 34.7 \\
\hline Severe Acute Pancreatitis & $7-10$ & 13 & 8.7 \\
\hline Total & & $\mathbf{1 5 0}$ & $\mathbf{1 0 0}$ \\
\hline
\end{tabular}

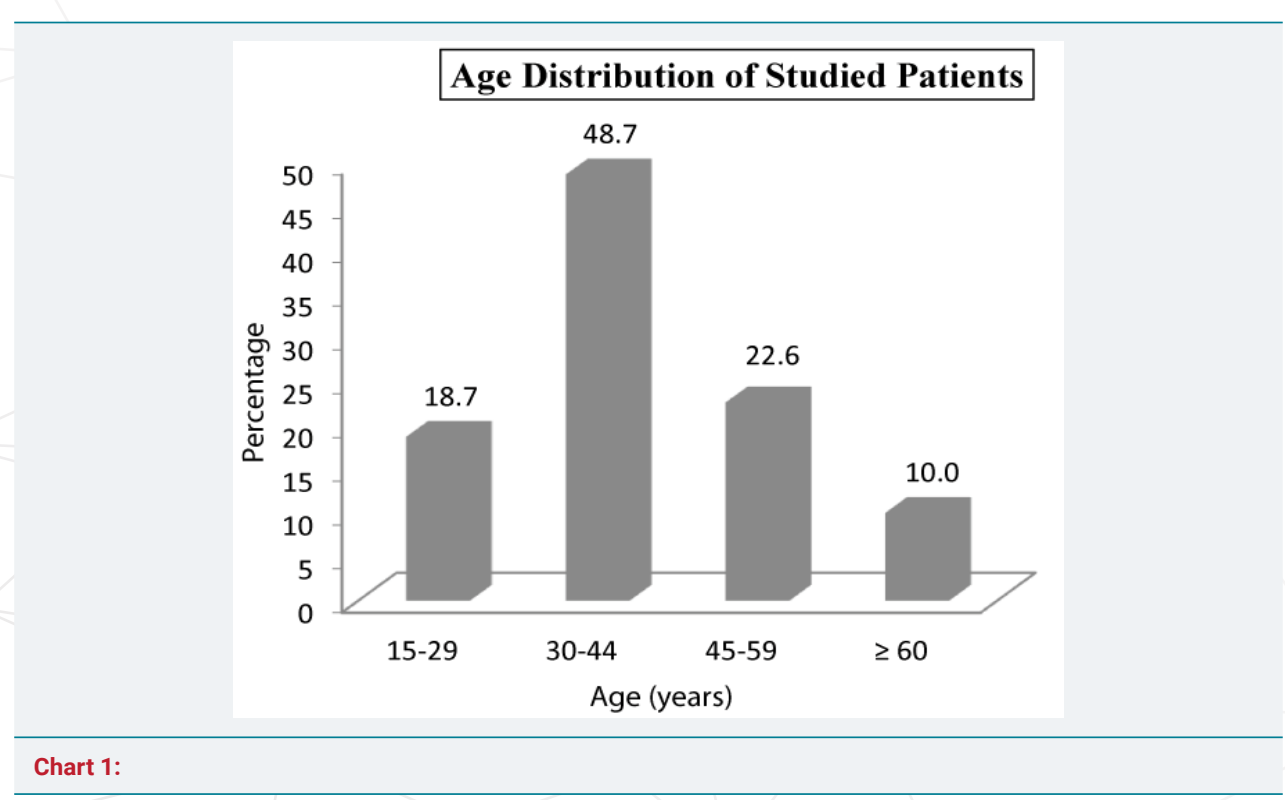



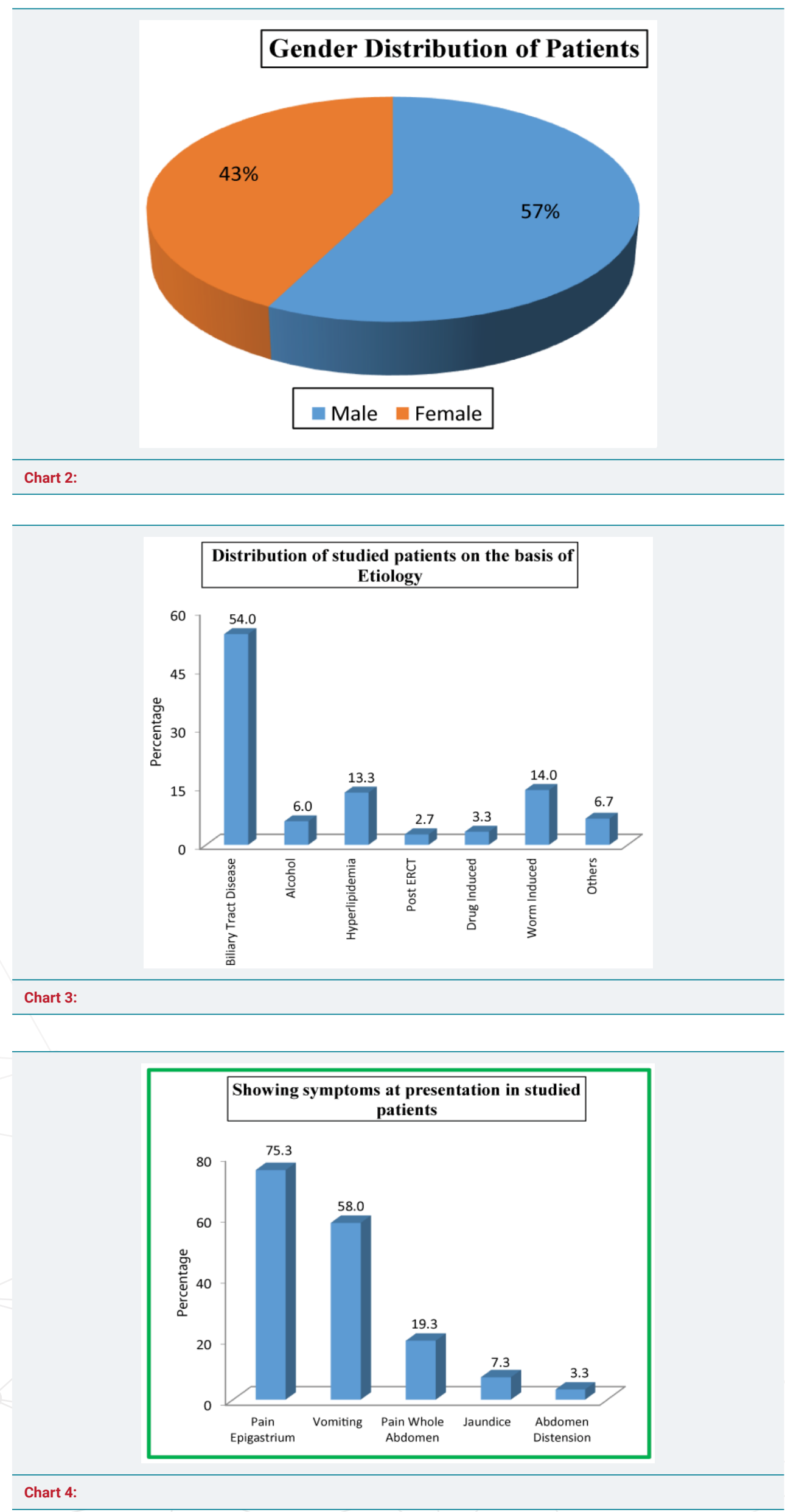

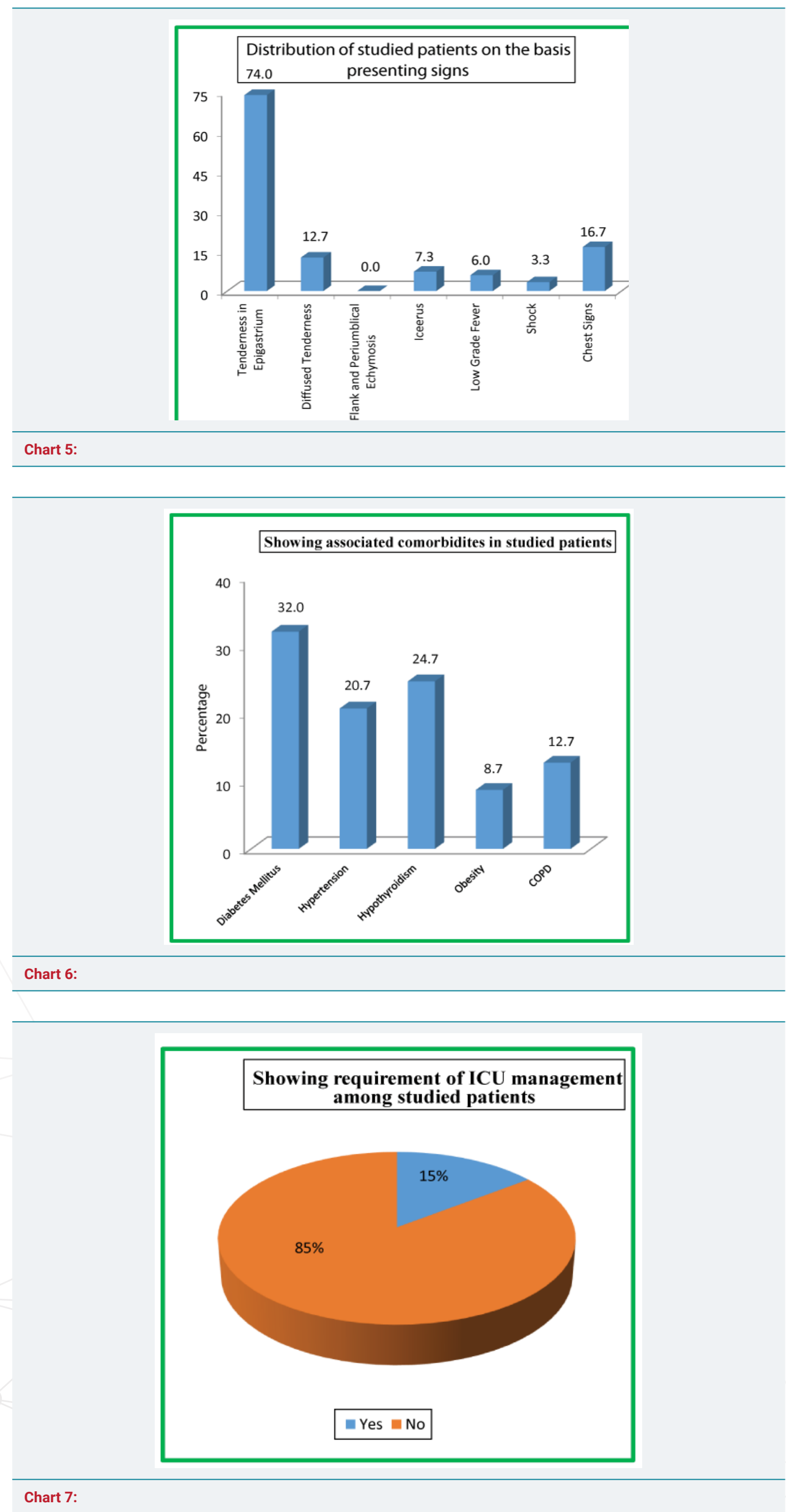

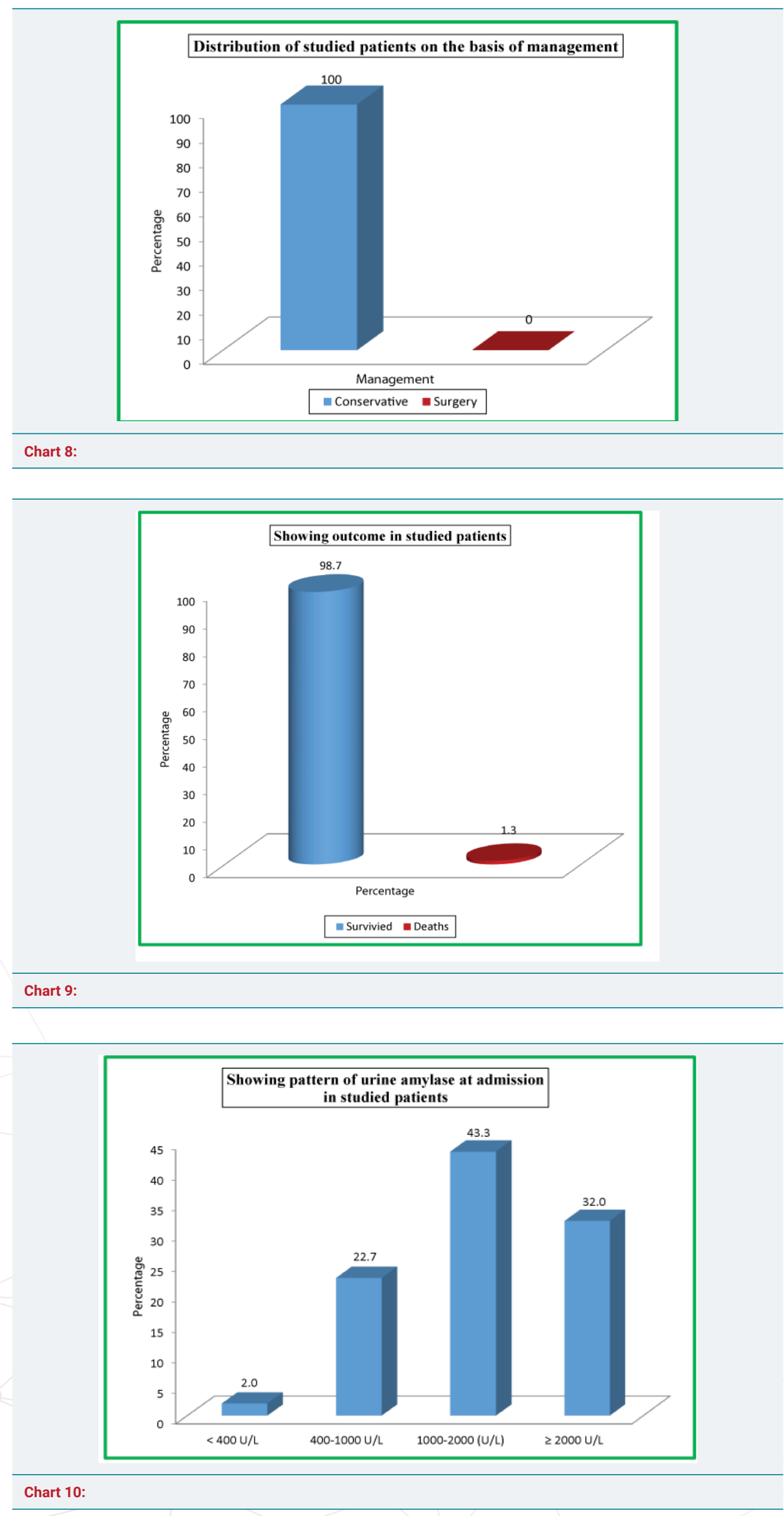

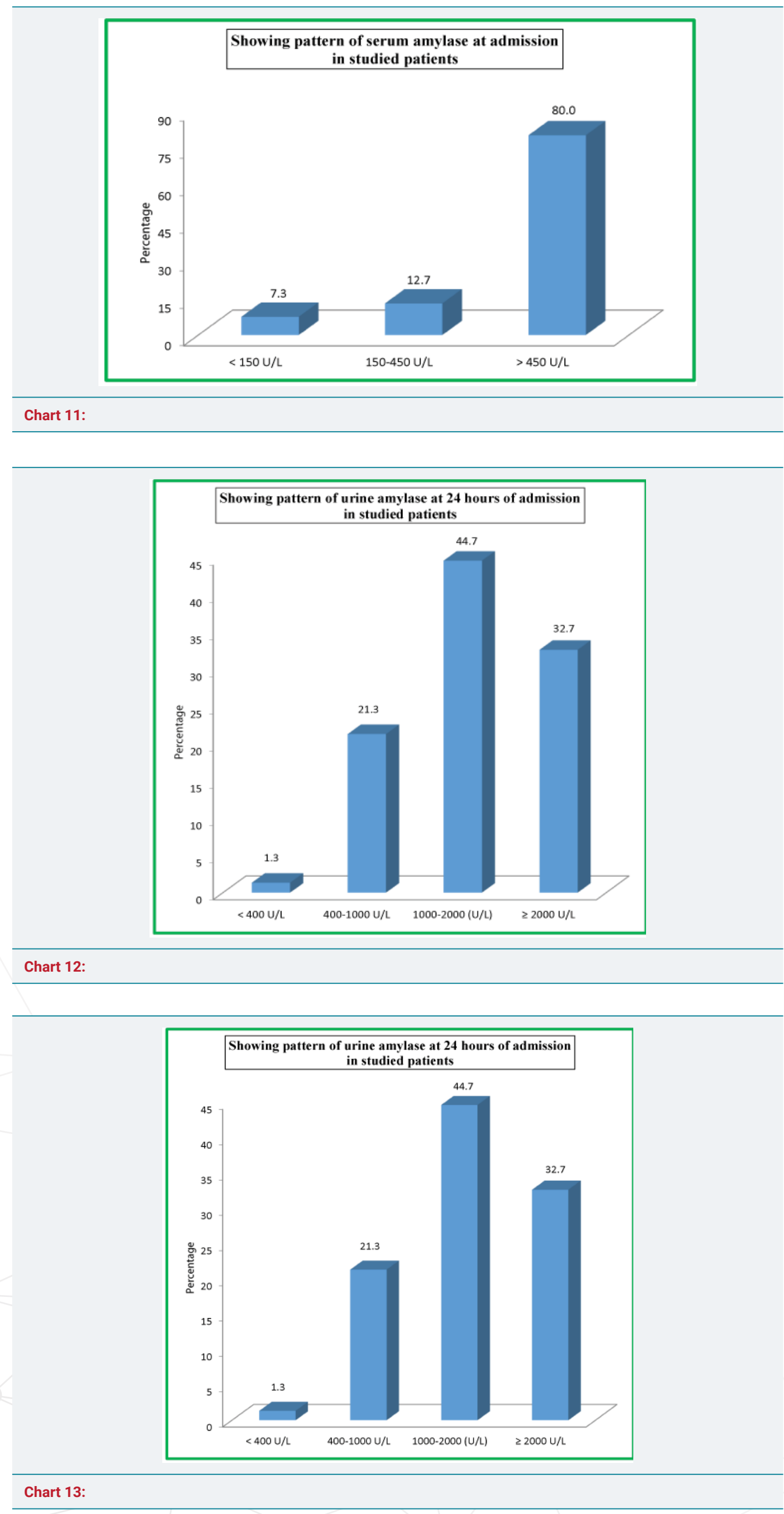


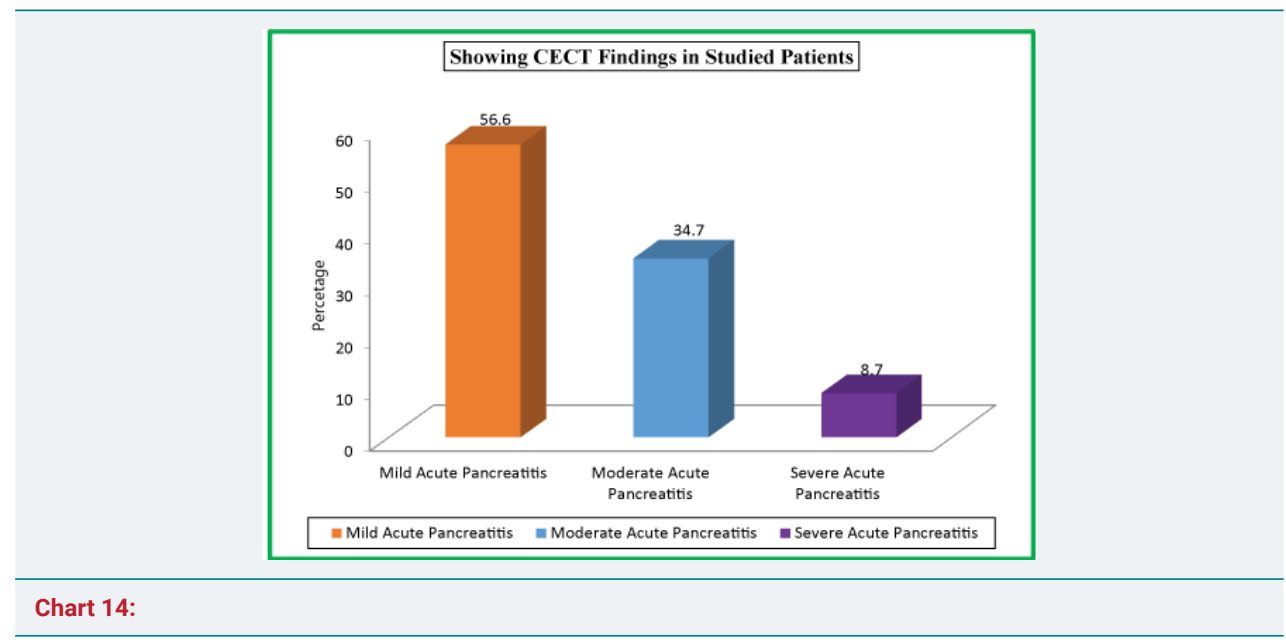

Tenderness in epigastrium was the presenting sign in $111(74 \%)$ of our studied subjects, followed by chest signs in 25 (16.7\%) patients, diffuse tenderness in 19 $(12.7 \%)$, icterus in $11(7.3 \%)$, low grade fever in $9(6 \%)$ patients, shock in $5(3.3 \%)$. None of the patients in our study had flank and periumblical ecchymosis as the present sign. Out of a total of 150 patients, majority 73 (48.7\%) belonged to age group of 30-44 years while as there were only $15(10 \%)$ patients aged $\geq 60$ years. In our study, we had $86(57.3 \%)$ male patients while as there were only $64(42.7 \%)$ female patients.

We had 81 (54\%) patients with biliary tract diseases, followed by 21 (14\%) patients with worm induced, 20 (13.3\%) had hyperlipidemia and only $4(2.7 \%)$ patients had post ERCP etiology. In our study, 113 (75.3\%) presented with pain epigastrium, following 87 (58\%) with vomiting, 29 (19.3\%) with pain whole abdomen, $11(7.3 \%)$ with jaundice and $5(3.3 \%)$ with abdomen distension. As far as associated comorbidities in the studied patients is concerned, diabetes mellitus was observed in $48(32 \%)$ patients, hypothyroidism in 37 (24.7\%) patients, hypertension in $31(20.7 \%)$ patients, COPD in 19 (12.7\%) patients and obesity in $13(8.7 \%)$ patients.

There were $22(14.7 \%)$ patients in our study population needed ICU admission; while as 128 (85.3\%) were managed in the general burn ward. All the enrolled patients in our study were managed conservatively. Out of a total of 150 patients, majority 148 $(98.7 \%)$ survived while as only $2(1.3 \%)$ patients expired. At the time of admission in the hospital, 120 (80\%) patients had serum amylase level of $>450 \mathrm{U} / \mathrm{L}, 19$ (12.7\%) patients had 150-450 U/L levels while as 11 (7.3\%) patients had <150 U/L serum amylase levels. At the time of admission in the hospital, 65 (43.3\%) patients had urinary amylase level of 1000-2000 U/L, 48 (32.0\%) patients had $\geq 2000 \mathrm{U} / \mathrm{L}$ levels, 34 $(22.7 \%)$ patients had $400-1000 \mathrm{U} / \mathrm{L}$ levels, while as only $3(2.0 \%)$ patients had $<400$ $\mathrm{U} / \mathrm{L}$ urinary amylase levels at the time of admission.

On comparing urinary amylase levels with serum amylase level at admission in the studied subjects, it was observed that 2 patients (18.2\%) had $<150 \mathrm{U} / \mathrm{L}, 0(0 \%) 150$ $450 \mathrm{U} / \mathrm{L}$ and $1(0.8 \%)>450 \mathrm{U} / \mathrm{L}$ serum amylase levels were having < $400 \mathrm{U} / \mathrm{L}$ urinary amylase levels. 2 (18.2\%), 9 (47.4\%) patients and $23(19.2 \%)$ with serum amylase levels of $<150,150-450$ and $>450$ UL were observed to have 400-1000 U/L urinary amylase levels. 7 (63.6\%), 7 (36.8\%) and 51 (42.5\%) patients were having 150, 150 450 and $>450 \mathrm{U} / \mathrm{L}$ when their urinary amylase levels were 1000-2000 U/L, while as patients with $\geq 2000 \mathrm{U} / \mathrm{L}$ urinary amylase levels were 3 (15.8\%) and 45 (37.5\%) with serum amylase levels of 150-450 and >450 U/L levels.

As far as urinary amylase levels at 24 hours is concerned, 67 (44.7\%) patients had urinary amylase level of 1000-2000 U/L, 49 (32.7\%) patients had $\geq 2000 \mathrm{U} / \mathrm{L}$ levels, 32 (21.3\%) patients had 400-1000 U/L levels, while as only $2(1.3 \%)$ patients had $<400$ 
U/L urinary amylase levels at 24 hours of admission. As far as urinary amylase levels at discharge is concerned, 69 (46\%) patients had urinary amylase level of 1000-2000 U/L, 51 (34\%) patients had $\geq 2000 \mathrm{U} / \mathrm{L}$ levels, 26 (17.3\%) patients had 400-1000 U/L levels, while as only $4(2.7 \%)$ patients had $<400 \mathrm{U} / \mathrm{L}$ urinary amylase levels at the time of discharge.

Out of a total of 150 patients, $85(56.7 \%)$ with CECT findings of mild acute pancreatitis had CTSI score of $0-3,52(34.7 \%)$ with CECT findings of moderate acute pancreatitis had CTSI score of 4-6 and only $13(8.7 \%)$ patients with CECT findings of severe acute pancreatitis had CTSI score of 7-10.

Table 17 and Chart 15 shows patients with mild pancreatitis (CTSI score of 0-3), moderate pancreatitis (CTSI score of 4-6) and severe pancreatitis (CTSI score of 7-10) association with urinary amylase at admission. $3(3.5 \%)$ were having mild pancreatitis when their urinary amylase level was <400 U/L. 22 (25.9\%), 10 (19.2\%) and 2 (15.4\%) patients had mild, moderate and sever pancreatitis when their urinary amylase level was 400-1000 U/L. 38 (44.7\%), 23 (44.2\%), 4 (30.8\%) patients were having mild, moderate and severe pancreatitis when their urinary amylase levels were 1000$2000 \mathrm{U} / \mathrm{L}$ while as patients with urinary amylase levels of $\geq 2000$ were having mild pancreatitis [22 (100\%)], moderate pancreatitis [16 (36.5\%)] and severe pancreatitis [7 (53.8\%)].

Table 18 shows patients with mild pancreatitis (CTSI score of $0-3$ ), moderate pancreatitis (CTSI score of 4-6) and severe pancreatitis (CTSI score of 7-10) association with urinary amylase at 24 hours of admission. $2(2.4 \%)$ were having mild pancreatitis when their urinary amylase level was <400 U/L. 20 (23.5\%), 9 (17.3\%) and $3(23.1 \%)$

\begin{tabular}{|c|c|c|c|c|c|c|}
\hline \multirow[t]{2}{*}{ Urinary Amylase } & \multicolumn{2}{|c|}{$\begin{array}{c}\text { Mild } \\
\text { (CTSI 0-3) }\end{array}$} & \multicolumn{2}{|c|}{ Moderate (CTSI 4-6) } & \multicolumn{2}{|c|}{$\begin{array}{c}\text { Severe } \\
\text { (CTSI 7-10) }\end{array}$} \\
\hline & No. & \%age & No. & \%age & No. & \%age \\
\hline$<400 \mathrm{U} / \mathrm{L}$ & 3 & 3.5 & 0 & 0.0 & 0 & 0.0 \\
\hline $400-1000 \mathrm{U} / \mathrm{L}$ & 22 & 25.9 & 10 & 19.2 & 2 & 15.4 \\
\hline $1000-2000(\mathrm{U} / \mathrm{L})$ & 38 & 44.7 & 23 & 44.2 & 4 & 30.8 \\
\hline$\geq 2000 \mathrm{U} / \mathrm{L}$ & 22 & 25.9 & 19 & 36.5 & 7 & 53.8 \\
\hline Total & 85 & 100 & 52 & 100 & 13 & 100 \\
\hline
\end{tabular}

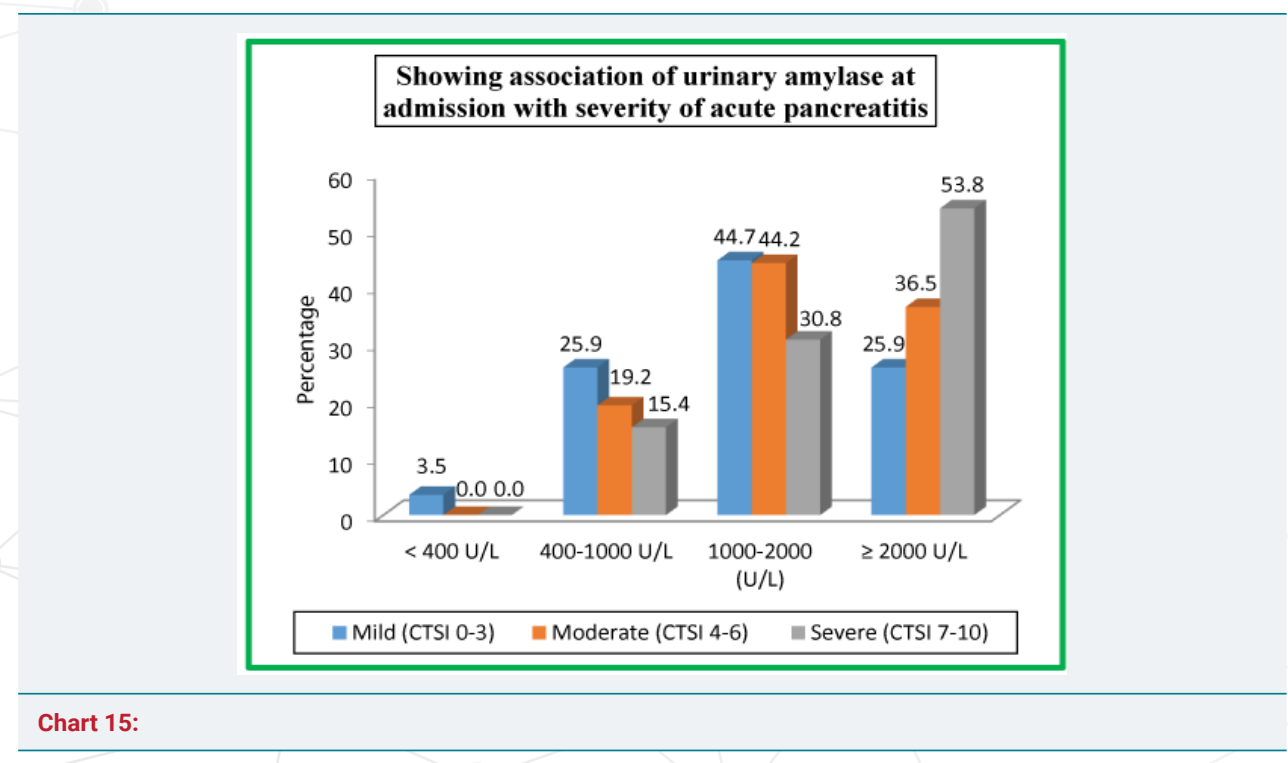


Table 18: Showing association of urinary amylase at 24 hours of admission with severity of acute pancreatitis.

\begin{tabular}{|c|c|c|c|c|c|c|}
\hline \multirow{2}{*}{$\begin{array}{c}\text { Mild } \\
\text { Urinary Amylase }\end{array}$} & \multicolumn{2}{c|}{ Moderate (CTSI 4-6) } & \multicolumn{2}{c|}{$\begin{array}{c}\text { Severe } \\
\text { (CTSI 7-10) }\end{array}$} \\
\hline & No. & \%age & No. & \%age & No. & $\%$ age \\
\hline$<400$ U/L & 2 & 2.4 & 0 & 0.0 & 0 & 0.0 \\
\hline $400-1000$ U/L & 20 & 23.5 & 9 & 17.3 & 3 & 23.1 \\
\hline $1000-2000$ (U/L) & 41 & 48.2 & 22 & 42.3 & 4 & 30.8 \\
\hline$\geq 2000$ U/L & 22 & 25.9 & 21 & 40.4 & 6 & 46.2 \\
\hline Total & $\mathbf{8 5}$ & $\mathbf{1 0 0}$ & $\mathbf{5 2}$ & $\mathbf{1 0 0}$ & $\mathbf{1 3}$ & $\mathbf{1 0 0}$ \\
\hline Chi-square= 5.9; P-value=0.437 & & & & & \\
\hline
\end{tabular}

patients had mild, moderate and sever pancreatitis when their urinary amylase level was 400-1000 U/L. 41 (48.2\%), 22 (42.3\%), 4 (30.8\%) patients were having mild, moderate and severe pancreatitis when their urinary amylase levels were 1000$2000 \mathrm{U} / \mathrm{L}$ while as patients with urinary amylase levels of $\geq 2000$ were having mild pancreatitis [22 (25.9\%)], moderate pancreatitis [21 (40.4\%)] and severe pancreatitis [6 (46.2\%)].

Table 19 shows patients with mild pancreatitis (CTSI score of 0-3), moderate pancreatitis (CTSI score of 4-6) and severe pancreatitis (CTSI score of 7-10) association with urinary amylase at the time of discharge. $3(3.5 \%)$ were having mild pancreatitis, $1(1.9 \%)$ moderate pancreatitis when their urinary amylase level was $<400 \mathrm{U} / \mathrm{L} .15$ (17.6\%), 9 (17.3\%) and $2(15.4 \%)$ patients had mild, moderate and sever pancreatitis when their urinary amylase level was 400-1000 U/L. 44 (51.8\%), 20 (38.5\%), 5 $(38.5 \%)$ patients were having mild, moderate and severe pancreatitis when their urinary amylase levels were 1000-2000 U/L while as patients with urinary amylase levels of $\geq 2000$ were having mild pancreatitis [23 (27.1\%)], moderate pancreatitis [22 $(42.3 \%)]$ and severe pancreatitis [6 (46.2\%)].

\section{DISCUSSION}

Acute pancreatitis makes a major chunk of our day to day admissions owing to the gallstone disease being seen predominantly in our part of the globe. The factors capable of precipitating acute pancreatitis are numerous and varied. Nevertheless, biliary lithiasis and alcohol together account for about $80 \%$ of the disease $[27,28]$. Historically, gallstones were recognised to be the predominant factor responsible for acute pancreatitis, representing 40 to 60 per cent of cases [29,30]. However, more recent reports suggest alcohol as the most common etiological factor [31,32].

Out of a total of 150 patients in our study, majority 73 (48.7\%) belonged to age group of 30-44 years while as there were only $15(10 \%)$ patients aged $>60$ years with $86(57.3 \%)$ males and $64(42.7 \%)$ females. Our results are somewhat comparable with the findings of the Prakash V. Chauhan et al. where in most affected age group was 50-59 years and mean age being 54 years [33]. As compared to female, male were more affected by acute pancreatitis in their study. In another study conducted by $\mathrm{P}$ Kandasami et al. [34], wherein the mean age of the patients was 43.5 years (SD \pm 14.7 years) and with 77 males and 56 females (M: F=1.4:1).

In our study we had $81(54 \%)$ patients with biliary tract diseases, followed by $21(14 \%)$ patients with worm induced, $20(13.3 \%)$ had hyperlipidemia and only 4 (2.7\%) patients had post ERCP etiology. Worm induced pancreatitis is more common in Kashmir. In order of occurrence, commonest causes in Males is alcoholism (66\%), followed by biliary diseases (8\%). While in Females biliary tract disease $(80 \%)$ leads. As in our society alcoholism is not that common in females [33]. The alcohol consumption is very minimal in Kashmir therefore the results are somewhat against. $\mathrm{P}$ Kandasami et al. studied alcohol as the predominant factor associated with acute pancreatitis in their study they noted 63 patients (47.7\%) alcoholic [34]. Twenty-one patients (15.9\%) were diagnosed to have gallstones pancreatitis and other factors 


\begin{tabular}{|c|c|c|c|c|c|c|}
\hline \multirow[t]{2}{*}{ Urinary Amylase } & \multicolumn{2}{|c|}{$\begin{array}{c}\text { Mild } \\
\text { (CTSI 0-3) }\end{array}$} & \multicolumn{2}{|c|}{ Moderate (CTSI 4-6) } & \multicolumn{2}{|c|}{$\begin{array}{c}\text { Severe } \\
\text { (CTSI 7-10) }\end{array}$} \\
\hline & No. & \%age & No. & \%age & No. & \%age \\
\hline$<400 \mathrm{U} / \mathrm{L}$ & 3 & 3.5 & 1 & 1.9 & 0 & 0.0 \\
\hline $400-1000 \mathrm{U} / \mathrm{L}$ & 15 & 17.6 & 9 & 17.3 & 2 & 15.4 \\
\hline $1000-2000(\mathrm{U} / \mathrm{L})$ & 44 & 51.8 & 20 & 38.5 & 5 & 38.5 \\
\hline$\geq 2000 \mathrm{U} / \mathrm{L}$ & 23 & 27.1 & 22 & 42.3 & 6 & 46.2 \\
\hline Total & 85 & 100 & 52 & 100 & 13 & 100 \\
\hline
\end{tabular}

identified in 13 patients included post ERCP; two patients (1.5\%) and hyperlipidemia. The drug induced pancreatitis is rarely seen in clinical practice but the observations of our study revealed that 3.3 percent ( 5 patients) manifested with acute pancreatitis. The historical background of these patients unraveled that they were on corticosteroids and diuretics for their co existent problems. In 36 patients (27.1\%), no known factors were identified. The results of $\mathbf{P}$ Kandasami et al., are differing from our observations the reasons could be multi-ethnicity in their studied population and vibrant use of alcohol in their studied areas [34].

In our study tenderness in epigastrium was the presenting sign in 111 (74\%), followed by chest signs in 25 (16.7\%) patients, diffuse tenderness in 19 (12.7\%), icterus in $11(7.3 \%)$, low grade fever in $9(6 \%)$ patients, shock in $5(3.3 \%)$. None of the patients in our study had flank and periumblical ecchymosis as the present sign. 113 (75.3\%) patients presented with pain epigastrium, following 87 (58\%) with vomiting, $29(19.3 \%)$ with pain whole abdomen, $11(7.3 \%)$ with jaundice and 5 (3.3\%) with abdomen distension. Nehal Naik et al., in their study observed $100 \%$ of the patient's pain abdomen as the presenting symptoms, $66 \%$ of them presented with nausea/ vomiting, $30 \%$ with abdominal distension, $8 \%$ with fever and $22 \%$ with jaundice [35]. In Manandhar et al., study, the most common symptoms at presentation was abdominal pain, followed by vomiting, fever and jaundice [36].

In our study, as far as associated comorbidities in the studied patients is concerned, diabetes mellitus was observed in 48 (32\%) patients, hypothyroidism in 37 (24.7\%) patients, hypertension in 31 (20.7\%) patients, COPD in 19 (12.7\%) patients and obesity in 13 (8.7\%) patients. Prakash V. Chauhan et al., in their study observed that $35 \%$ patients had one or more comorbidities like type 2 diabetes mellitus, hypertension, ischemic heart disease, chronic obstructive airway disease or chronic liver disease [33].

In our study population $22(14.7 \%)$ needed ICU admission; while as 128 (85.3\%) were managed in the general ward. All the enrolled patients in our study were managed conservatively. The principles of conservative management followed in each case were adequate analgesia, correction of fluid and electrolytes imbalance, complete GI tract rest and Antibiotics. Our study is consistent with the findings of Keita Terui et al., wherein the authors observed that overall conservative management is favorable over surgical management [37]. Another study done by Prakash V. Chauhan et al., wherein $38(76 \%)$ patients were conservatively managed and only $12(24 \%)$ were operated upon [33].

In our study, out of a total of 150 patients, 148 (98.7\%) survived while as only $2(1.3 \%)$ patients expired. The severity of AP forms a continuum, and the average mortality rate approaches $2-10 \%$ [2]. Singh VK et al., studied 397 patients in which 14 $(3.5 \%)$ died [38].

At the time of admission in the hospital, $120(80 \%)$ patients had serum amylase level of $>450 \mathrm{U} / \mathrm{L}, 19$ (12.7\%) patients had 150-450 U/L levels while as 11 (7.3\%) patients had $<150 \mathrm{U} / \mathrm{L}$ serum amylase levels. 
In a study done Nehal Naik et al., most (92\%) of the patient's serum amylase was 3 fold above normal value which is consistent with the findings of the present study [35]. Serum amylase level was again raised in $76.3 \%$ of patients studied by Keita Terui et al. [37]. Serum amylase level is elevated in all patients during the initial period of acute pancreatitis in a series of 352 patients with acute pancreatitis admitted to clinic of digestive surgery, Geneva University hospital revealed that hyperamylasemia is seen in $81 \%$ of patients [33].

On comparing urinary amylase levels with serum amylase level at admission in the studied subjects, it was observed that 2 patients (18.2\%) had <150 U/L, $0(0 \%) 150$ $450 \mathrm{U} / \mathrm{L}$ and $1(0.8 \%)>450 \mathrm{U} / \mathrm{L}$ serum amylase levels were having < $400 \mathrm{U} / \mathrm{L}$ urinary amylase levels. 2 (18.2\%), 9 (47.4\%) patients and $23(19.2 \%)$ with serum amylase levels of $<150,150-450$ and $>450$ UL were observed to have 400-1000 U/L urinary amylase levels. 7 (63.6\%), 7 (36.8\%) and 51 (42.5\%) patients were having 150, 150 450 and $>450 \mathrm{U} / \mathrm{L}$ when their urinary amylase levels were 1000-2000 U/L, while as patients with $\geq 2000 \mathrm{U} / \mathrm{L}$ urinary amylase levels were 3 (15.8\%) and 45 (37.5\%) with serum amylase levels of 150-450 and $>450 \mathrm{U} / \mathrm{L}$ levels. With regards to correlation analysis, urinary amylase had the best correlation with serum amylase at admission ( $\mathrm{p}<0.001)$. In 273 samples (34.0\% of all samples), when serum amylase was over the standard level, urinary amylase also had the best correlation with serum amylase $(\mathrm{p}<$ 0.001) [37]. The results are in accordance with the findings of the present study.

The urinary amylase excretion is a highly sensitive indicator of the presence of acute pancreatitis. In the absence of renal insufficiency, the urinary excretion remained always abnormal when the serum concentration was abnormal, and the excretion remained abnormal for 2 to 50 days even after the serum concentration had returned to normal. Thus the urinary amylase excretion is a useful monitor for the diagnosis of subsiding pancreatitis and for convalescent care of acute pancreatitis [39].

In many cases, urinary clearance of pancreatic enzymes from the circulation increases during pancreatitis; therefore, urinary levels may be more sensitive than serum levels. For these reasons, it is recommended that amylase concentrations also be measured in the urine. Urinary amylase levels usually remain elevated for several days after serum levels have returned to normal [40].

The observations of our study in this regard can be perused from table 12 . The results show that the levels of urinary amylase and serum amylase in pancreatitis do not always correlate to each other with reference to severity of pancreatitis.

At the time of admission in the hospital, 65 (43.3\%) patients had urinary amylase level of 1000-2000 U/L, 48 (32.0\%) patients had $\geq 2000 \mathrm{U} / \mathrm{L}$ levels, 34 (22.7\%) patients had 400-1000 U/L levels, while as only $3(2.0 \%)$ patients had $<400 \mathrm{U} / \mathrm{L}$ urinary amylase levels at the time of admission. As far as urinary amylase levels at 24 hours is concerned, 67 (44.7\%) patients had urinary amylase level of 1000-2000 U/L, 49 (32.7\%) patients had $\geq 2000$ U/L levels, 32 (21.3\%) patients had 400-1000 $\mathrm{U} / \mathrm{L}$ levels, while as only $2(1.3 \%)$ patients had $<400 \mathrm{U} / \mathrm{L}$ urinary amylase levels at 24 hours of admission. As far as urinary amylase levels at discharge is concerned, 69 (46\%) patients had urinary amylase level of 1000-2000 U/L, 51 (34\%) patients had $\geq 2000$ U/L levels, 26 (17.3\%) patients had 400-1000 U/L levels, while as only 4 (2.7\%) patients had $<400 \mathrm{U} / \mathrm{L}$ urinary amylase levels at the time of discharge.

Out of a total of 150 patients, 85 (56.7\%) with CECT findings of mild acute pancreatitis had CTSI score of $0-3,52$ (34.7\%) with CECT findings of moderate acute pancreatitis had CTSI score of 4-6 and only 13 (8.7\%) patients with CECT findings of severe acute pancreatitis had CTSI score of 7-10.

Patients with mild pancreatitis (CTSI score of 0-3), moderate pancreatitis (CTSI score of 4-6) and severe pancreatitis (CTSI score of 7-10) association with urinary 
amylase at admission. 3 (3.5\%) were having mild pancreatitis when their urinary amylase level was <400 U/L. 22 (25.9\%), 10 (19.2\%) and 2 (15.4\%) patients had mild, moderate and severe pancreatitis when their urinary amylase level was 4001000 U/L. 38 (44.7\%), 23 (44.2\%), 4 (30.8\%) patients were having mild, moderate and severe pancreatitis when their urinary amylase levels were 1000-2000 U/L while as patients with urinary amylase levels of $\geq 2000$ were having mild pancreatitis [22 (100\%)], moderate pancreatitis [16 (36.5\%)] and severe pancreatitis [7 (53.8\%)].

In our study we showed patients with mild pancreatitis (CTSI score of 0-3), moderate pancreatitis (CTSI score of 4-6) and severe pancreatitis (CTSI score of 7-10) association with urinary amylase at 24 hours of admission. 2 (2.4\%) were having mild pancreatitis when their urinary amylase level was <400 U/L. 20 (23.5\%), 9 (17.3\%) and $3(23.1 \%)$ patients had mild, moderate and severe pancreatitis when their urinary amylase level was 400-1000 U/L. 41 (48.2\%), 22 (42.3\%), 4 (30.8\%) patients were having mild, moderate and severe pancreatitis when their urinary amylase levels were 1000-2000 U/L while as patients with urinary amylase levels of $\geq 2000$ were having mild pancreatitis [22 (25.9\%)], moderate pancreatitis [21 (40.4\%)] and severe pancreatitis [6 (46.2\%)].

Present study shows patients with mild pancreatitis (CTSI score of 0-3), moderate pancreatitis (CTSI score of 4-6) and severe pancreatitis (CTSI score of 7-10) association with urinary amylase at the time of discharge. $3(3.5 \%)$ were having mild pancreatitis, $1(1.9 \%)$ moderate pancreatitis when their urinary amylase level was $<400 \mathrm{U} / \mathrm{L} .15$ (17.6\%), 9 (17.3\%) and $2(15.4 \%)$ patients had mild, moderate and sever pancreatitis when their urinary amylase level was 400-1000 U/L. 44 (51.8\%), 20 (38.5\%), 5 (38.5\%) patients were having mild, moderate and severe pancreatitis when their urinary amylase levels were 1000-2000 U/L while as patients with urinary amylase levels of $\geq 2000$ were having mild pancreatitis [23 (27.1\%)], moderate pancreatitis [22 (42.3\%)] and severe pancreatitis [6 (46.2\%)]. The above findings could not be discussed with any literature because we could not find any direct study correlating CT findings with urinary amylase.

\section{CONCLUSION}

The urinary amylase excretion is a highly sensitive indicator of the presence of acute pancreatitis. The urinary excretion remained always abnormal when the serum concentration was abnormal, and the excretion remained abnormal for long time even after the serum concentration had returned to normal. Thus the urinary amylase excretion is a useful monitor for the diagnosis of subsiding pancreatitis and for convalescent care of acute pancreatitis. Urinary clearance of pancreatic enzymes from the circulation increases during pancreatitis; therefore, urinary levels may be more sensitive than serum levels. For these reasons, it is recommended that amylase concentrations also be measured in the urine. Urinary amylase levels usually remain elevated for several days after serum levels have returned to normal.

Urinary amylase was found to significantly correlate with serum amylase at admission, and therefore may be of use as an alternative to serum amylase during management of patients with hyperamylasemia. Use of urine samples results in a decreased number of blood samples.

\section{REFERENCES}

1. Clavien PA, Robert J, Meyer P, Borst F, Hauser $\mathrm{H}$. Acute pancreatitis and normoamylasemia. Not an uncommon combination. Ann Surg. 1989; 210: 614-620. Ref.: https://goo.gl/nKZpfJ

2. Mann DV, Hershman MJ, Hittinger R, Glazer G. Multicentre audit of death from acute pancreatitis. $\mathrm{Br}$ J Surg. 1994; 81: 890-893. Ref.: https://goo.gl/dG5yzW

3. Banerjee AK, Kaul A, Bache E, Parberry AC, Doran J, et al. An audit of fatal acute pancreatitis. Postgrad Med J. 1995; 71: 472-475. Ref.: https://goo.gl/FpnKtZ 
4. Gronroos J, Nylamo E. Mortality in acute pancreatitis in Turku University Central Hospital 1971-1995. Hepato-Gastroenterol. 1999; 46: 2572-2574. Ref.: https://goo.gl/YvmkY9

5. Steinberg W, Tenner S. Acute pancreatitis. N Engl J Med. 1994; 330: 1198-1210. Ref.: https://goo.gl/kX6jos

6. Barie PS. A critical review of antibiotic prophylaxis in severe acute pancreatitis. Am J Surg. 1996; 172: 38-43. Ref.: https://goo.gl/LJfFsv

7. Beger HG, Bittner R, Block S, Buchler M. Bacterial contamination of pancreatic necrosis. A prospective clinical study. Gastroenterology. 1986; 91: 433-438. Ref.: https://goo.gl/7tqoQM

8. Dubick MA, Mar G, Mayer AD, Majumdar AP, McMahon MJ, et al. Digestive enzymes and protease inhibitors in plasma from patients with acute pancreatitis. Pancreas. 1987; 2: 187-194. Ref.: https://goo.gl/H8XbP8

9. Clavien PA, Burgan S, Moossa AR. Serum enzymes and other laboratory tests in acute pancreatitis. Br J Surg. 1989; 76: 1234-1243. Ref.: https://goo.gl/i8gcDp

10. Steer ML, Meldolesi J, Figarella C. Pancreatitis. The role of lysosomes. Dig Dis Sci. 1984; 29: $934-$ 938. Ref.: https://goo.gl/W92jMq

11. Steer $M$. Büchler $M$, Uhl W, Friess $H$, Malfertheimer $P$. Primary intracellular events in pancreatitis. In: Acute pancreatitis, novel concepts in biology and treatment. Berlin Vienna, Blackwell WissenschaftsVerlag. 1999; 4-12.

12. Marshall J. Acute pancreatitis. A review with an emphasis on new developments. Arch Intern Med. 1993; 153: 1185-1198. Ref.: https://goo.gl/8wCJvo

13. Durie $P$, Gaskin KJ, Geokas MC, $O^{`}$ Rourke M, Largman C. Plasma immunoreactive anionic pancreatic trypsin in cystic fibrosis. J Pediatr Gastroenterol Nutr. 1982; 1: 337-343. Ref.: https://goo.gl/GkVrSP

14. Gudgeon A, Heath D, Hurley P, Jehanli A, Patel G, et al. Trypsinogen activation peptides assay in the early prediction of severity of acute pancreatitis. Lancet. 1990; 335: 4-8. Ref.: https://goo.gl/ph2NXe

15. Neoptolemos J, Kemppainen E, Mayer J, Fitzpatrick J, Raraty M, et al. Early prediction of severity in acute pancreatitis by urinary trypsinogen activation peptide: a multicentre study. Lancet. 2000; 355 : 1955-1960. Ref.: https://goo.gl/tUKnMz

16. Ohlsson K. Acute pancreatitis. Biochemical, pathophysiological and therapeutic aspects. Acta Gastroenterol Belg. 1988; 51: 3-12. Ref.: https://goo.gl/DMi2M3

17. Glasbrenner B, Adler G. Pathophysiology of acute pancreatitis. Hepatogastroenterology. 1993; 40 : 517-521. Ref.: https://goo.gl/KUbW9f

18. Osman M, Jensen S. Acute pancreatitis: The pathophysiological role of cytokines and integrins. Dig Surg. 1999; 16: 347-362. Ref.: https://goo.gl/Ax4VAi

19. Lerch MM, Saluja AK, Dawra R, Ramarao $P$, Saluja $M$, et al. Acute necrotizing pancreatitis in the opossum: earliest morphological changes involve acinar cells. Gastroenterology. 1992; 103: 205213. Ref.: https://goo.gl/cWuQ4t

20. Runzi M, Saluja A, Lerch M, Dawra R, Nishino H, et al. Early ductal decompression prevents the progression of biliary panreatitis: an experimental study in the opossum. Gastroenterology 1993 105: 157-164. Ref.: https://goo.gl/37w2Qn

21. Buchler M. Objectification of the severity of acute pancreatitis. Hepatogastroenterology. 1991 38:101-108. Ref.: https://goo.gl/edBUvq

22. Bone R. Towards a theory regarding the pathogenesis of the systemic inflammatory response syndrome: What we do and do not know about cytokine regulation. Crit Care Med. 1996; 24: 163172. Ref.: https://goo.gl/tyagLz

23. De Beaux AC, Palmer KR, Carter DC. Factors influencing morbidity and mortality in acute pancreatitis; an analysis of 279 cases. Gut. 1995; 37: 121-126. Ref.: https://goo.gl/vkdkay

24. Neoptolemos J, Carr-Locke D, London N, Bailey I, James D, et al. Controlled trial of urgent endoscopic retrograde cholangiopancreatography and endoscopic sphincterotomy versus conservative treatment for acute pancreatitis due to gall stones. Lancet. 1988; 332: 979-983. Ref.: https://goo.gl/jrF48r

25. Kanwar S, Windsor A, Reynolds JV. Early enteral nutrition in acute pancreatitis. Nutrition. 1999; 15 951-952. Ref.: https://goo.gl/p1NYzC 
26. Piironen A, Kivisaari R, Pitkäranta $P$, Poutanen V, Laippala $P$, et al. Contrast enhanced magnetic resonance imaging for the detection of acute haemorrhagic necrotizing pancreatitis. Eur Radiol. 1997; 7: 17-20. Ref.: https://goo.gl/RRFrR4

27. John RP. Acute pancreatitis. Surg Clin North Am. 1988; 68: 281-299. Ref.: https://goo.gl/jUZvqT

28. Mergener K, Baillie J. Acute pancreatitis. BMJ. 1998; 316: 44-48. Ref.: https://goo.gl/XeMHYY

29. Thomson HJ. Acute pancreatitis north and north-east Scotland. J R Coll Surg Edinb. 1985; 30: 104111. Ref.: https://goo.gl/rcMGuX

30. Liu CL, Lo CM, Fan ST. Acute Biliary Pancreatitis: Diagnosis and Management. World J Surg. 1997; 21: 149-154. Ref.: https://goo.gl/v2Zxcq

31. Corfield AP, Cooper MJ, Williamson RC. Acute pancreatitis: a lethal disease of increasing incidence. Gut. 1985; 26: 724-729. Ref.: https://goo.gl/ZzCmTM

32. Lankisch PG, Schirren CA, Schmidt H, Schonfelder G, Creutzfeldt W. Etiology and incidence of acute pancreatitis: a 20-year study in a single institution. Digestion. 1989; 44: 20-25. Ref.: https://goo.gl/KXEaBE

33. Chauhan PV, Patel RR. Research and Analytical Study of 50 Cases of Acute Pancreatitis. International Journal of Science and Research. 2012; 475-478.

34. Kandasami P, Harunarashid H, Harjit K. Acute Pancreatitis in a Multi-Ethnic Population. Singapore Med J. 2002; 43: 284-288. Ref.: https://goo.gl/oirgoL

35. Naik N, Patel G, Parmar H. Etiology, age and sex distribution, investigations and treatment of gallstone pancreatitis. IAIM. 2016; 3: 46-50. Ref.: https://goo.gl/yTrKxE

36. Manandhar S, Giri S, Poudel P, Bhandari RS, Lakhey PJ, et al. Acute biliary pancreatitis: an experience in a tertiary level hospital of Nepal. Indian J Surg. 2013; 75: 449-453. Ref.: https://goo.gl/WqVdFG

37. Terui $K$, Hishiki $T$, Saito $T$, Mitsunaga $T$, Nakata $M$, et al. Urinary amylase/urinary creatinine ratio (uAm/uCr)-a less-invasive parameter for management of hyperamylasemia. BMC Pediatrics. 2013; 13: 205. Ref.: https://goo.gl/yDbfmQ

38. Singh VK, Wu BU, Bollen TL, Repas K, Maurer R, et al. A prospective evaluation of the bedside index for severity in acute pancreatitis score in assessing mortality and intermediate markers of severity in acute pancreatitis. Am J Gastroenterol. 2009; 104: 966-971. Ref.: https://goo.gl/cx8ENu

39. Hayakawa T. Clinical significance of urinary amylase in diagnosis of pancreatic diseases. Nagoya $\mathrm{J}$ Med Sci. 1970; 32: 185-214. Ref.: https://goo.gl/SDjEXe

40. Fisher WE, Andersen DK, John A, et al. Charles Brunicardi. Pancreas. Chapter 33 In: Schwartz's Principles of Surgery. $10^{\text {th }}$ Edition. 1356. 